\title{
Pre- and postoperative left ventricular contractile function in patients with aortic valve disease ${ }^{1}$
}

\author{
H. P. KRAYENBUEHL, M. TURINA, O. M. HESS, M. ROTHLIN, AND \\ A. SENNING \\ From the Department of Internal Medicine, Medical Policlinic, Cardiology, and Surgical Clinic A, \\ University of Zurich, Zurich, Switzerland
}

SUMMARY In 43 patients left ventricular micromanometry and cineangiography were performed preoperatively and 20 months after aortic valve replacement. A score of left ventricular functional impairment, derived from 5 to 8 haemodynamic variables, was calculated as: number of pathological indices $\times 100 /$ total number of determined indices. Preoperatively the score of left ventricular functional impairment amounted to 35 per cent in group 1 (aortic stenosis: $n=19$ ), to 61 per cent in group 2 (combined lesion: $n=15)(P<0.05)$, and to 87 per cent in group 3 (aortic regurgitation: $n=9)(P<$ 0.001 ). In contrast, the functional classification according to the NYHA showed similar impairment in the 3 groups. Postoperatively the score of left ventricular functional impairment decreased significantly in all 3 groups to 10,16 , and 27 per cent, respectively, but the score of group 3 remained raised $(P<0.05)$ as compared with that of group 1 . The patients with residual left ventricular dysfunction had a higher preoperative left ventricular muscle mass than the patients with normal or near normal postoperative left ventricular function.

It is concluded that (1) at similar functional impairment according to the NYHA classification left ventricular contractile function is more severely impaired in aortic regurgitation and in aortic regurgitation + aortic stenosis than in aortic stenosis alone, (2) left ventricular function improves significantly after valve replacement in all three forms of aortic valve disease, (3) residual functional impairment is greater in aortic regurgitation than in aortic stenosis or aortic stenosis + aortic regurgitation, and (4) persistent postoperative left ventricular functional impairment is found in the patients with severe preoperative hypertrophy.

The outcome of aortic valve replacement with respect to mortality and long-term postoperative thromboembolic complications has been the subject of numerous reports (Björk et al., 1974; Hirshfeld et al.,1974; Isom et al., 1974; Barnhorst et al., 1975; Rothlin et al., 1977 ) but there is only limited information regarding myocardial function after successful surgery (Gault et al., 1970; Doces et al., 1974; Schmutzler et al., 1976). However, the postoperative quality of life and ultimately the fate of the patient with aortic valve disease is determined by the functional state of the left ventricular myocardium. Thus it is important to know to what extent preoperatively compromised left ventricular function is reversible

'Supported by a grant from the Swiss National Science Foundation.

Received for publication 17 March 1978 after surgery. Obviously this would influence our indications for valve replacement, which, in most centres at present, are based essentially on the patient's complaints. The relation of overall functional limitation (NYHA classification) to the actual myocardial function may vary in different forms of aortic valve disease. It was the purpose of the present study to compare preoperative left ventricular function with that after surgery in patients with aortic stenosis, aortic regurgitation, and combined aortic valve disease. We assessed in the same groups the relation of preoperative invasive left ventricular function to the overall functional impairment according to the NYHA classification. We also studied procedures thought to be useful for myocardial protection during surgery to see whether they had any impact on the long-term contractile state of the left ventricular myocardium. 
sle 1 Clinical data

\begin{tabular}{|c|c|c|c|c|c|c|c|c|c|c|}
\hline & $\begin{array}{l}\text { Age }(y) \\
\text { Preop }\end{array}$ & Postop & $\begin{array}{l}\text { NYHA cla } \\
\text { Preop }\end{array}$ & $\begin{array}{l}\text { iss } \\
\text { Postop }\end{array}$ & $\begin{array}{l}\text { PWC } \\
\text { (\% of norm } \\
\text { Preop }\end{array}$ & $\stackrel{\text { Postop }}{\text { Pol }}$ & $\begin{array}{l}\text { SOKI } \\
(m V) \\
\text { Preop }\end{array}$ & Postop & $\begin{array}{l}\text { Restudy } \\
\text { (mth) } \\
\text { postop }\end{array}$ & Comments \\
\hline $\begin{array}{l}\text { up } 1 \text { (aortic stenosis) } \\
\text { nber }\end{array}$ & $\begin{array}{l}52 \pm 8 \\
19\end{array}$ & $\begin{array}{l}54 \pm 8 \\
19\end{array}$ & $\begin{array}{l}2.8 \\
\pm 0.6 \\
19 \\
\quad<0.001\end{array}$ & $\begin{array}{l}1.4 \\
\pm 0.6 \\
19\end{array}$ & $\begin{array}{l}70 \pm 26 \\
18 \\
<0.02\end{array}$ & $\begin{array}{l}87 \pm 14 \\
19\end{array}$ & $\begin{array}{l}4.8 \\
\pm 1 \cdot 2 \\
16 \\
\quad<0.001\end{array}$ & $\begin{array}{l}3 \cdot 5 \\
\pm 1 \cdot 2 \\
16\end{array}$ & $\begin{array}{l}16 \cdot 6 \\
\pm 5 \cdot 9 \\
19\end{array}$ & $\begin{array}{l}1 \text { PDA; } 2 \text { LBBB, } \\
1 \text { RBBB } \\
\text { Cor. arteriography in } \\
16 / 19 \text { patients }\end{array}$ \\
\hline $\begin{array}{l}\text { up } 2 \text { (aortic stenosis } \\
\text { regurgitation) } \\
\text { nber }\end{array}$ & $\begin{array}{l}44 \pm 9 \\
15\end{array}$ & $\begin{array}{l}46 \pm 9 \\
15\end{array}$ & $\begin{array}{l}2.7 \\
\pm 0.6 \\
15 \\
\quad<0.001\end{array}$ & $\begin{array}{l}1 \cdot 4 \\
\pm 0.5 \\
15\end{array}$ & $\begin{array}{l}70 \pm 18 \\
15<0.01\end{array}$ & $\begin{array}{l}88 \pm 16 \\
15\end{array}$ & $\begin{array}{l}6.2 \\
\pm 2 \cdot 1 \\
14 \quad<0.001\end{array}$ & $\begin{array}{l}3 \cdot 8 \\
\pm 1 \cdot 2 \\
14\end{array}$ & $\begin{array}{l}20 \cdot 7 \\
\pm 8 \cdot 8 \\
15\end{array}$ & $\begin{array}{l}1 \text { LAD stenosis } 75 \% \text {, } \\
1 \text { VSD, } 1 \text { LBBB } \\
\text { Cor. arteriography in } \\
11 / 15 \text { patients }\end{array}$ \\
\hline $\begin{array}{l}\text { up } 3 \text { (aortic } \\
\text { :gurgitation) } \\
\text { nber }\end{array}$ & $\begin{array}{l}41 \pm 9 \\
9\end{array}$ & $\begin{array}{l}43 \pm 10 \\
9\end{array}$ & $\begin{array}{l}2.4 \\
\pm 0.5 \\
\quad<0.01\end{array}$ & $\begin{array}{l}1.3 \\
\pm 0.5 \\
9\end{array}$ & $\begin{array}{l}67 \pm 22 \\
8 \\
<0.025\end{array}$ & $\begin{array}{l}86 \pm 18 \\
9\end{array}$ & $\begin{array}{l}5.8 \\
\pm 81.6 \\
\quad<0.005\end{array}$ & $\begin{array}{l}3.6 \\
\pm 0.8 \\
8\end{array}$ & $\begin{array}{l}26 \cdot 0 \\
\pm 14 \cdot 2 \\
9\end{array}$ & $\begin{array}{l}1 \text { LBBB } \\
\text { Cor. arteriography in } \\
2 / 9 \text { patients }\end{array}$ \\
\hline $\begin{array}{l}\text { vs } 2 \\
\text { v8 } 3 \\
\text { v8 } 3\end{array}$ & $\begin{array}{l}<0.01 \\
<0.005 \\
\text { NS }\end{array}$ & NS & $\begin{array}{l}\text { NS } \\
\text { NS } \\
\text { NS }\end{array}$ & $\begin{array}{l}\text { NS } \\
\text { NS } \\
\text { NS }\end{array}$ & $\begin{array}{l}\text { NS } \\
\text { NS } \\
\text { NS }\end{array}$ & $\begin{array}{l}\text { NS } \\
\text { NS } \\
\text { NS }\end{array}$ & $\begin{array}{l}<0.05 \\
\text { NS } \\
\text { NS }\end{array}$ & $\begin{array}{l}\text { NS } \\
\text { NS } \\
\text { NS }\end{array}$ & $\begin{array}{l}\text { NS } \\
<0.02 \\
\text { NS }\end{array}$ & \\
\hline
\end{tabular}

C, physical working capacity; SOKI, Sokolow index for left ventricular hypertrophy $\left(\right.$ SV $_{1}+\mathbf{R V}_{\mathrm{B}}$ or 8 ); PDA, persistent ductus arteriosus; LBBB and $B B$, left and right bundle-branch block; $L A D$, left anterior descending coronary artery; VSD, ventricular septal defect; $P$, probability (paired $t$ test); probability (unpaired $t$ test); NS, not significant.

\section{Subjects and methods}

\section{PATIENTS}

Forty-three patients (39 men; 4 women) with aortic valve disease were evaluated by right and left heart catheterisation and cineangiography before operation and 20 (range 11 to 55) months after aortic valve replacement (Table 1). Group 1 consisted of 19 patients with aortic stenosis. These patients had a mean systolic pressure gradient across the aortic valve between 51 and $131 \mathrm{mmHg}$ and none or only slight aortic regurgitation (regurgitation fraction as determined by thermodilution $<0 \cdot 18$ ). Group 2 consisted of 15 patients with a combined aortic valve lesion (mean systolic pressure gradient 28 to $87 \mathrm{mmHg}$, aortic regurgitation fraction 0.22 to 0.70 ). In group 3 there were 9 patients with aortic regurgitation (regurgitation fraction 0.58 to 0.84 ). Coronary arteriography was carried out in 29 patients. In only one patient in group 2 was there a significant $(>50 \%$ ) coronary arierial stenosis. Of the 14 patients in whom the coronary arteries were not visualised selectively, 10 were below the age of 43 years. Associated minor valvular or congenital lesions included minimal to slight mitral regurgitation in 17 patients, persistent ductus arteriosus in 1 , and ventricular septal defect in 1 .

All patients were in sinus rhythm before and after operation. Apart from 5 patients who showed a stable left or right bundle-branch block, the duration of the QRS complex was within normal limits. Patients in whom a bundle-branch block appeared after surgery were excluded from the study. Most patients were on maintenance digitalis before and/or after valve replacement. Overall physical working capacity was evaluated by bicycle ergometry in the sitting position. The achieved number of watts at the submaximal heart rate was expressed as a percentage of the normal value for a given height, age, and sex.

CATHETERISATION AND CINEANGIOGRAPHY Informed consent was obtained from all patients. Premedication consisted of $10 \mathrm{mg}$ chlordiazepoxide or $5 \mathrm{mg}$ diazepam given orally 1 hour before the procedure. Left ventricular pressure was measured in 32 patients by a transseptally introduced micromanometer (Statham SF-1 or Millar) at both preand postoperative catheterisation. In 5 patients micromanometer measurements were obtained solely at the postoperative study. In six patients only conventional left ventricular pressure measurements were obtained. From the high fidelity left ventricular curves that were recorded at a paper speed of 200 $\mathrm{mm} / \mathrm{s}$ (oscillograph Electronics for Medicine DR/16) the first derivative $(\mathrm{dP} / \mathrm{dt})$ and the instantaneous quotient $(\mathrm{dP} / \mathrm{dt}) / \mathrm{P}$ were obtained by an analogue computer (Krayenbuehl et al., 1973). The peak value of $(\mathrm{dP} / \mathrm{dt}$ )/P was labelled Vpm (peak measured velocity of shortening) and expressed in muscle lengths (ML)/s, a constant of series elasticity of 28 being used (Mirsky et al., 1971). Total pressure Vmax was determined by linear extrapolation of the descending limb of the pressure-velocity curves (Krayenbuehl et al., 1973). This was done only when at least 3 data points on the descending limb before aortic valve opening were available. 
Monoplane left ventricular cineangiography in the right anterior oblique position was performed at midinspiration at a fiuming rate of 50 or 75 frames per second. Quantitative evaluation of end-diastolic and end-systolic frames for the calculation of enddiastolic volume, ejection fraction, mean normalised systolic ejection rate, and mean velocity of endocardial circumferential shortening was carried out as reported previously (Brunner et al., 1977). End-diastolic wall thickness was determined in most instances from a second left ventricular cineangiogram obtained in the anteroposterior position or occasionally from the first angiogram in the right anterior oblique position. Left ventricular muscle mass was calculated according to the technique of Rackley et al. (1964).

\section{ASSESSMENT OF LEFT VENTRICULAR CONTRACTILE FUNCTION}

Isovolumic as well as ejection phase indices have been used for quantifying the functional state of the left ventricular myocardium. However, no single index is valid under all haemodynamic conditions (Peterson et al., 1974; Kreulen et al., 1975; Brunner et al., 1977). Therefore, a score derived from 5 to 8 variables including left ventricular enddiastolic pressure, cardiac index, end-diastolic volume index, ejection fraction, mean velocity of endocardial circumferential shortening, mean normalised systolic ejection rate, peak measured velocity of shortening, and total pressure Vmax was established for describing left ventricular contractile function. The score of left ventricular functional impairment was calculated as: number of pathological indices $\times 100 /$ total number of determined indices. Table 2 indicates the criteria when a given index of left ventricular function was considered to be pathological (Brunner et al., 1977). The total number of determined indices included all 8 variables in 60 instances, 7 variables in 8 instances, 6 in 17 instances, and 5 in 1 instance.

SURGICAL PROCEDURE (Table 3)

A Björk-Shiley prosthesis (no. 19 to 31 , average
Table 2 Indices used for establishing score of left ventricular functional impairment

\begin{tabular}{ll}
\hline & Pathological when: \\
\hline $\begin{array}{l}\text { Left ventricular end-diastolic pressure } \\
(\mathrm{mmHg})\end{array}$ & $>12$ \\
Cardiac index $\left(1 / \mathrm{min}\right.$ per $\left.\mathrm{m}^{2}\right)$ & $<2.5$ \\
End-diastolic volume index $\left(\mathrm{ml} / \mathrm{m}^{2}\right)$ & $>121$ \\
Ejection fraction & $<0.62$ \\
Mean velocity of circumferential fibre & $<1.00$ \\
$\quad$ shortening (circ/s) & $<2.00$ \\
Mean normalised systolic ejection rate & $<1.14$ \\
$\quad(\mathrm{EDVs} / \mathrm{s})$ & $<1.47$ \\
$\operatorname{Vpm}(\mathrm{ML} / \mathrm{s})$ & $<\mathrm{ML} / \mathrm{s})$
\end{tabular}

Vpm, peak measured velocity of contractile element shortening; Vmax, extrapolated maximal velocity of contractile element shortening; EDV, end-diastolic volume; circ, circumferences.

tissue annulus diameter $25 \cdot 2 \pm 2 \cdot 1 \mathrm{~mm}$ ) was inserted in 32 patients, and a Lillehei-Kaster (no. 16 to 20 , average tissue annulus diameter $25 \cdot 0 \pm 1 \cdot 8$ $\mathrm{mm})$ prosthesis was inserted in 11 patients. Postoperative paravalvular leakage occurred in only 1 patient of group 2 who had a postoperative aortic regurgitation fraction of 0.30 . In 1 patient an aortocoronary bypass to the left anterior descending coronary artery was carried out but was found to be occluded at the postoperative evaluation. A persistent ductus arteriosus and a small ventricular septal defect were closed. Myocardial protection during cardiopulmonary bypass consisted of (1) $30^{\circ}$ anoxic arrest $(n=13),(2)$ coronary flush with 1000 $\mathrm{ml} 4^{\circ}$ Ringers solution ( $\left.\mathrm{n}=24\right)$, and ( 3 ) biochemical cardioplegia* $(n=6)$. In order to evaluate possible intraoperative damage, a score including intraoperative events and early postoperative complications was established (Table 4). The scoring technique was such that at a high score there was an increased probability of intraoperative myocardial damage.

^ $200 \mathrm{ml}$ Cardioplegin (Dr Frank Köhler Chemie, Alsbach, West Germany) injected directed into the coronary arteries.

Table 3 Surgical data

\begin{tabular}{|c|c|c|c|c|c|c|}
\hline & Björk-Shiley & Lillehei-Kaster & $\begin{array}{l}30^{\circ} \text { anoxic } \\
\text { arrest }\end{array}$ & $\begin{array}{l}\text { Cold coronary } \\
\text { flush }\end{array}$ & $\begin{array}{l}\text { Biochemical } \\
\text { cardioplegia }\end{array}$ & Comments \\
\hline Group 1 (aortic stenosis) $(n=19)$ & 13 & 6 & 7 & 10 & 2 & \multirow{2}{*}{$\begin{array}{l}\text { Closure of PDA in } \\
1 \text { patient } \\
\text { Closure of VSD in } 1 \\
\text { patient; ACBP in } 1 \\
\text { patient occluded at } \\
\text { postop study }\end{array}$} \\
\hline $\begin{array}{l}\text { Group } 2 \text { (aortic stenosis } \\
\quad+\text { regurgitation) }(n=15)\end{array}$ & 13 & 2 & 4 & 10 & 1 & \\
\hline
\end{tabular}

PDA, persistent ductus arteriosus; VSD, ventricular septal defect; ACBP, aortocoronary bypass. 
Table 4 Score for the evaluation of intraoperative myocardial damage

\begin{tabular}{|c|c|c|c|}
\hline & \multicolumn{3}{|c|}{ Score points } \\
\hline & 1 & 2 & 3 \\
\hline In anoxic arrest and cold coronary flush & $<40 \mathrm{~min}$ & 40 to $60 \mathrm{~min}$ & $>60 \mathrm{~min}$ \\
\hline In biochemical cardioplegia & $<50 \mathrm{~min}$ & 50 to $70 \mathrm{~min}$ & $>70 \mathrm{~min}$ \\
\hline Duration of cardiopulmonary bypass & $<70 \mathrm{~min}$ & 70 to $90 \mathrm{~min}$ & $>90 \mathrm{~min}$ \\
\hline Emergency operation & No & Yes & \\
\hline Number of defibrillations & 1 to 2 & 3 to 5 & $>5$ \\
\hline Duration of bypass support after beginning of coronary reperfusion & $<20 \mathrm{~min}$ & 20 to $30 \mathrm{~min}$ & $>30 \mathrm{~min}$ \\
\hline Duration of intubation & $<2 \mathrm{~d}$ & 2 to $4 \mathrm{~d}$ & $>4 \mathrm{~d}$ \\
\hline Postoperative catecholamines & $<12 \mathrm{~h}$ & 12 to $48 \mathrm{~h}$ & $>48 \mathrm{~h}$ \\
\hline
\end{tabular}

\section{Results}

\section{CLINICAL DATA}

Overall functional limitation, according to the classification of the NYHA, and the reduction of ergometric physical working capacity were similar in the 3 groups of patients before operation. After aortic valve replacement there was a significant improvement in both the NYHA score and the physical working capacity in all groups (Table 1). Left ventricular hypertrophy as assessed by the Sokolow index was highest before operation in group 2 . After operation this index decreased significantly in all 3 groups, and the postoperative mean values were at or slightly above the upper limit of normal $(3.5 \mathrm{mV})$.

\section{LEFT VENTRICULAR FUNCTION}

(Tables 5 and 6)

Before operation the left ventricular end-diastolic pressure was raised in all 3 groups but the increase was significantly larger in groups 2 and 3 than in group 1. After operation the end-diastolic pressure decreased significantly to values in the upper range of normal. The end-diastolic volume index before operation was increased in groups 2 and 3 and was in the upper range of normal in group 1. After operation there was a significant decrease in enddiastolic volume index in all 3 groups, the extent of reduction being largest in the patients with aortic regurgitation who had the largest preoperative ventricular volume. Cardiac index did not differ significantly between the 3 groups before operation and remained unchanged after surgery. Preoperatively the isovolumic (peak measured velocity of shortening, Vmax) as well as the ejection phase (ejection fraction, mean normalised systolic ejection rate, and mean velocity of endocardial circumferential shortening) indices were normal or only slightly depressed in group 1 (aortic stenosis) but were clearly pathological in group 3 (aortic regurgitation). In group 2 (aortic stenosis and regurgitation) the indices of left ventricular contractile function were intermediate. After operation there was a significant increase in practically all contractile indices. However, normalisation was generally less complete in aortic regurgitation than in aortic stenosis; again the patients with the combined lesion showed intermediate values.

Before operation the score of left ventricular functional impairment was highest in aortic regurgitation, lowest in aortic stenosis, and intermediate in aortic stenosis plus regurgitation (Fig. 1). After aortic valve replacement there was a significant reduction of the score of left ventricular functional impairment in all 3 groups. Though the extent of decrease was largest in aortic regurgitation the score remained significantly raised in aortic regurgitation as compared with aortic stenosis (Fig. 1). Thus, there was a residual postoperative impairment of left ventricular contracile function in the patients with aortic regurgitation.

\section{PREOPERATIVE LEFT VENTRICULAR FUNCTION AND FUNCTIONAL CLASSES ACCORDING TO NYHA}

There was no close correlation between the overall functional limitation (NYHA class) and the impairment of left ventricular contractile function. At a given NYHA class the score of left ventricular functional impairment was significantly greater in aortic regurgitation than in aortic stenosis whereas the values for the patients with combined aortic valve lesion were intermediate (Fig. 2).

\section{SCORE OF POTENTIAL INTRAOPERATIVE DAMAGE, MEASURES OF INTRAOPERATIVE MYOCARDIAL PROTECTION, AND POSTOPERATIVE LEFT VENTRICULAR FUNCTION}

The score of potential intraoperative damage amounted to 11.2 points in group 1 , to 13.3 points in group $2(P<0.01$ vs. group 1 ), and to 12.6 points in group 3 (not significantly different as com- 
Table 5 Haemodynamic data

\begin{tabular}{|c|c|c|c|c|c|c|c|c|}
\hline & \multicolumn{2}{|c|}{$\begin{array}{l}\text { Left ventricular peak } \\
\text { systolic pressure }(\mathrm{mmHg})\end{array}$} & \multicolumn{2}{|c|}{$\begin{array}{l}\text { Left ventricular end- } \\
\text { diastolic pressure }(\mathrm{mmHg})\end{array}$} & \multicolumn{2}{|c|}{ Heart rate (bpm) } & \multicolumn{2}{|c|}{$\begin{array}{l}\text { Cardiac index } \\
\left.\text { (l/min per } m^{2}\right)\end{array}$} \\
\hline & Preop & Postop & Preop & Postop & Preop & Postop & Preop & Postop \\
\hline $\begin{array}{l}\text { Group } 1 \text { (aortic stenosis) } \\
\text { Number } \\
\text { P }\end{array}$ & $\begin{array}{l}220 \pm 33 \\
19 \quad<0.001\end{array}$ & $\begin{array}{l}161 \pm 31 \\
19\end{array}$ & 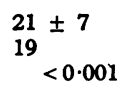 & $\begin{array}{l}13 \pm 3 \\
19\end{array}$ & $\begin{array}{l}76 \pm 19 \\
19 \\
\text { NS }\end{array}$ & $\begin{array}{l}79 \pm 16 \\
19\end{array}$ & $\begin{array}{l}3 \cdot 1 \pm 0 \cdot 7 \\
19 \\
\quad \text { NS }\end{array}$ & $\begin{array}{l}3 \cdot 1 \pm \\
19\end{array}$ \\
\hline $\begin{array}{l}\text { Group } 2 \text { (aortic stenosis } \\
\quad+\text { regurgitation) } \\
\text { Number } \\
\mathbf{P}\end{array}$ & $\begin{array}{l}185 \pm 30 \\
15<0.001\end{array}$ & $\begin{array}{l}135 \pm 18 \\
15\end{array}$ & $\begin{array}{l}29 \pm 10 \\
15 \\
<0.001\end{array}$ & $\begin{array}{l}11 \pm 3 \\
15\end{array}$ & $\begin{array}{l}73 \pm 10 \\
15 \\
\text { NS }\end{array}$ & $\begin{array}{l}71 \\
15\end{array}$ & $\begin{array}{l}2.9 \pm 0.7 \\
15 \\
\text { NS }\end{array}$ & $\begin{array}{l}3 \cdot 1 \pm \\
15\end{array}$ \\
\hline $\begin{array}{l}\text { Group } 3 \text { (aortic regurgitation) } \\
\text { Number } \\
\mathbf{P}\end{array}$ & $\begin{array}{l}136 \pm 10 \\
9 \\
\text { NS }\end{array}$ & $\begin{array}{c}136 \\
9\end{array}$ & $\begin{aligned} 37 & \pm 16 \\
9 & <0.001\end{aligned}$ & $\underset{9}{10} \pm 2$ & $\begin{array}{l}78 \pm 15 \\
9 \\
\text { NS }\end{array}$ & $\underset{9}{72} \pm 12$ & $\begin{array}{l}2 \cdot 6 \pm 1 \cdot 1 \\
9 \\
\text { NS }\end{array}$ & $\begin{array}{c}3 \cdot 0 \pm \\
9\end{array}$ \\
\hline $\begin{array}{l}P \star_{1} \text { vs } \\
P \star_{1} \text { v8 } \\
P \star_{2} \text { v8 }\end{array}$ & $\begin{array}{l}<0.005 \\
<0.001 \\
<0.001\end{array}$ & $\begin{array}{l}<0.01 \\
<0.05 \\
\text { NS }\end{array}$ & $\begin{array}{l}<0.02 \\
<0.001 \\
\text { NS }\end{array}$ & $\begin{array}{l}\text { NS } \\
<0.025 \\
\text { NS }\end{array}$ & $\begin{array}{l}\text { NS } \\
\text { NS } \\
\text { NS }\end{array}$ & $\begin{array}{l}\text { NS } \\
\text { NS } \\
\text { NS }\end{array}$ & $\begin{array}{l}\text { NS } \\
\text { NS } \\
\text { NS }\end{array}$ & $\begin{array}{l}\text { NS } \\
\text { NS } \\
\text { NS }\end{array}$ \\
\hline
\end{tabular}

Vpm, peak measured velocity of contractile element shortening; Vmax, extrapolated maximal velocity of contractile element shortening; $P$, prob bility (paired t test); $\mathbf{P}^{\star}$, probability (unpaired $t$ test).

pared with groups 1 and 2). When the patients were grouped according to the measure of intraoperative myocardial protection ( $30^{\circ}$ anoxic arrest, cold coronary flush, biochemical cardioplegia), there was no significant difference among these groups either with respect to the score of potential intraoperative damage or with respect to the postoperative score of left ventricular functional impairment. Comparison between the score of potentional intraoperative damage and the score of postoperative left ventricular functional impairment showed no significant correlation (correlation coefficient $0 \cdot 10$ ).

LEFT VENTRICULAR WALL THICKNESS AND MUSCLE MASS (Table 6)

In groups 1 and 2 the preoperatively increased left ventricular end-diastolic wall thickness decreased significantly after operation to values at or slightly larger than the upper limit of normal in our laboratory (1.04 cm (Brunner et al., 1977)). In group 3 wall thickness remained unchanged after operation. Left ventricular muscle mass index decreased significantly in all 3 groups, the postoperative mean values reaching the upper limit of our normal range (50 to $129 \mathrm{~g} / \mathrm{m}^{2}$ (Brunner et al., 1977)).

\section{Discussion}

\section{PREOPERATIVE FINDINGS}

With respect to the preoperative overall functional limitation the 3 subgroups of aortic valve disease appeared to be comparable because the average NYHA class and the ergometrically determined physical working capacity were of similar magnitude.

Table 6 Angiographic data

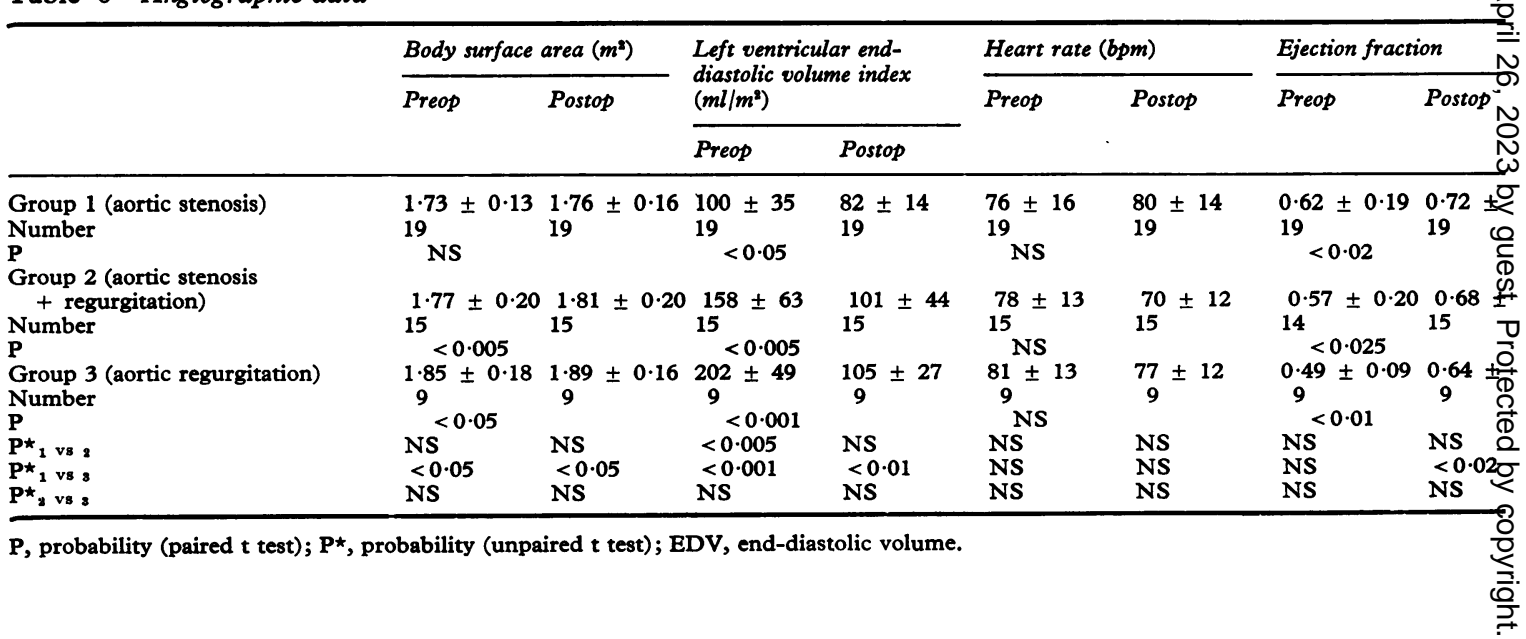




\begin{tabular}{|c|c|c|c|c|c|c|c|c|c|}
\hline \multirow{2}{*}{\multicolumn{2}{|c|}{$\begin{array}{l}\text { sstolic pressure } \\
\text { across aortic } \\
\text { tmHg) }\end{array}$}} & \multicolumn{2}{|c|}{ Aortic valve area $\left(\mathrm{cm}^{2}\right)$} & \multicolumn{2}{|c|}{$\max d P / d t(m m H g / s)$} & \multicolumn{2}{|l|}{$V p m(M L / s)$} & \multicolumn{2}{|l|}{$V \max (M L / s)$} \\
\hline & & \multirow[t]{2}{*}{ Preop } & \multirow[t]{2}{*}{ Postop } & \multirow[t]{2}{*}{ Preop } & \multirow[t]{2}{*}{ Postop } & \multirow[t]{2}{*}{ Preop } & \multirow[t]{2}{*}{ Postop } & \multirow[t]{2}{*}{ Preop } & \multirow[t]{2}{*}{ Postop } \\
\hline & Postop & & & & & & & & \\
\hline $\begin{array}{l}9 \\
01\end{array}$ & $\begin{array}{l}19 \pm 16 \\
19\end{array}$ & $\begin{array}{l}0.56 \pm 0.15 \\
19\end{array}$ & $\begin{array}{l}1.05 \pm 0.38 \\
13\end{array}$ & $\begin{array}{l}2230 \pm 450 \\
16 \\
\quad \text { NS }\end{array}$ & $\begin{array}{l}2120 \pm 590 \\
18\end{array}$ & $\begin{array}{l}1.33 \pm 0.23 \\
16 \\
\quad<0.001\end{array}$ & $\begin{array}{l}1 \cdot 70 \pm 0.38 \\
18\end{array}$ & $\begin{array}{l}1.74 \pm 0.32 \\
16 \\
\quad<0.005\end{array}$ & $\begin{array}{l}2 \cdot 13 \pm 0 \cdot 46 \\
18\end{array}$ \\
\hline $\begin{array}{l}9 \\
01\end{array}$ & $\begin{array}{l}13 \pm 9 \\
15\end{array}$ & $\begin{array}{l}1 \cdot 14 \pm 0 \cdot 77 \\
15\end{array}$ & $\begin{array}{l}1.49 \pm 0.39 \\
11\end{array}$ & $\begin{array}{l}1420 \pm 350 \\
11<0.02\end{array}$ & $\begin{array}{l}1600 \pm 310 \\
13\end{array}$ & $\begin{array}{l}0.87 \pm 0.27 \\
11<0.001\end{array}$ & $\begin{array}{l}1.37 \pm 0.30 \\
13\end{array}$ & $\begin{array}{c}1.34 \pm 0.30 \\
8<0.02\end{array}$ & $\begin{array}{l}1 \cdot 72 \pm 0.37 \\
13\end{array}$ \\
\hline \multirow{2}{*}{01} & $\underset{9}{11} \pm 9$ & & $\underset{6}{1.51} \pm 0.43$ & $\begin{array}{c}1050 \pm 200 \\
6<0.05\end{array}$ & $\frac{1320}{5} \pm 160$ & $\begin{array}{c}0.77 \pm 0.20 \\
6 \quad<0.005\end{array}$ & $\frac{1 \cdot 38}{5} \pm 0 \cdot 21$ & & $\frac{1.67}{5} \pm 0.25$ \\
\hline & $\begin{array}{l}\text { NS } \\
\text { NS } \\
\text { NS }\end{array}$ & $<0.005$ & $\begin{array}{l}<0.01 \\
<0.05 \\
\text { NS }\end{array}$ & $\begin{array}{l}<0.001 \\
<0.001 \\
<0.05\end{array}$ & $\begin{array}{l}<0.01 \\
<0.01 \\
\text { NS }\end{array}$ & $\begin{array}{l}<0.001 \\
<0.001 \\
\text { NS }\end{array}$ & $\begin{array}{l}<0.02 \\
\text { NS } \\
\text { NS }\end{array}$ & $<0.01$ & $\begin{array}{l}<0.02 \\
<0.05 \\
\text { NS }\end{array}$ \\
\hline
\end{tabular}

However, left ventricular contractile function was dissimilar in the three forms of aortic valve disease, the score of left ventricular functional impairment being significantly higher in aortic regurgitation and in combined valve lesion than in aortic stenosis (Fig. 1). This finding is important with respect to the indication of aortic valve surgery based on the patient's symptoms. It means that in aortic regurgitation and in combined aortic valve lesions deterioration of myocardial function is more advanced than in aortic stenosis when the patient becomes symptomatic and hence is selected for valve replacement. Thus, it is not surprising that long-term postoperative survival has been reported by several authors (Hirshfeld et al., 1974; Isom et al., 1974; Barnhorst et al., 1975; Rothlin et al., 1977) to be less favourable in aortic regurgitation and combined valve lesions than in aortic stenosis alone.

\section{POSTOPERATIVE LEFT VENTRICULAR} CONTRACTILE FUNCTION

In keeping with other postoperative haemodynamic studies in isolated aortic valve disease (Hultgren et al., 1969; Kloster et al., 1970; Lee et al., 1970; Björk et al., 1973a, b; Lurie et al., 1977) left ventricular end-diastolic pressure returned to normal on average. Left ventricular ejection performance as assessed by the ejection fraction increased postoperatively to normal values in all 3 forms of aortic valve disease (Table 6 ). This observation is in agreement with other investigations (Doces et al., 1974; Schmutzler et al., 1976) dealing with angiographic assessment of left ventricular function after successful aortic valve replacement. In contrast, no significant postoperative change of left ventricular ejection fraction was reported in patients with aortic homografts (Kennedy et al., 1968) or porcine

\begin{tabular}{|c|c|c|c|c|c|c|c|c|c|}
\hline \multicolumn{2}{|c|}{ t time (ms) } & \multicolumn{2}{|c|}{$\begin{array}{l}\text { Mean normalised systolic } \\
\text { ejection rate }(E D V / s)\end{array}$} & \multirow{2}{*}{\multicolumn{2}{|c|}{$\begin{array}{l}\text { Mean velocity of } \\
\text { circumferential fibre } \\
\text { shortening (circ/s) }\end{array}$}} & \multicolumn{2}{|c|}{$\begin{array}{l}\text { Left ventricular end- } \\
\text { diastolic wall thickness }(\mathrm{cm})\end{array}$} & \multicolumn{2}{|c|}{$\begin{array}{l}\text { Left ventricular muscle } \\
\text { mass index }\left(\mathrm{g} / \mathrm{m}^{2}\right)\end{array}$} \\
\hline & \multirow{2}{*}{ Postop } & \multirow{2}{*}{$\overline{\text { Preop }}$} & \multirow{2}{*}{ Postop } & & & \multirow{2}{*}{ Preop } & \multirow{2}{*}{ Postop } & \multirow{2}{*}{ Preop } & \multirow{2}{*}{ Postop } \\
\hline & & & & Preop & Postop & & & & \\
\hline 28 & $\begin{array}{l}288 \pm 28 \\
19\end{array}$ & $\begin{array}{l}1.96 \pm 0.57 \\
19\end{array}$ & $\begin{array}{l}2 \cdot 51 \pm 0 \cdot 29 \\
19\end{array}$ & $\begin{array}{l}1.05 \pm 0.44 \\
19\end{array}$ & $\begin{array}{l}1.53 \pm 0.28 \\
19\end{array}$ & $\begin{array}{l}1 \cdot 18 \pm 0 \cdot 17 \\
19\end{array}$ & $\begin{array}{l}1 \cdot 03 \pm 0 \cdot 14 \\
19\end{array}$ & $\begin{array}{l}154 \pm 48 \\
19\end{array}$ & $\begin{array}{l}116 \pm 28 \\
19\end{array}$ \\
\hline 105 & & $<0.001$ & & $<0.001$ & & $<0.001$ & & $<0.001$ & \\
\hline 35 & $\begin{array}{l}293 \pm 26 \\
15\end{array}$ & $\begin{array}{l}1.80 \pm 0.67 \\
14\end{array}$ & $\begin{array}{l}2.36 \pm 0.59 \\
14\end{array}$ & $\begin{array}{l}0.97 \pm 0.51 \\
15\end{array}$ & $\begin{array}{l}1.38 \pm 0.34 \\
15\end{array}$ & $\begin{array}{l}1 \cdot 21 \pm 0 \cdot 17 \\
15\end{array}$ & $\begin{array}{l}1.07 \pm 0.20 \\
15\end{array}$ & $\begin{array}{l}201 \pm 48 \\
15\end{array}$ & $\begin{array}{l}132 \pm 38 \\
15\end{array}$ \\
\hline $\begin{array}{l}15 \\
18\end{array}$ & $291 \pm 32$ & $\begin{array}{c}<0.02 \\
1.54 \pm 0.28 \\
9\end{array}$ & $\underset{9}{2 \cdot 23} \pm 0.49$ & $\begin{array}{c}<0.02 \\
0.69 \pm 0.28 \\
9\end{array}$ & $\underset{9}{1 \cdot 25} \pm 0.51$ & $\begin{array}{c}<0.02 \\
1.03 \pm 0.26 \\
9\end{array}$ & $\underset{9}{1.04} \pm 0.10$ & $\begin{array}{c}<0.001 \\
190 \pm 76 \\
9\end{array}$ & $\begin{array}{c}130 \\
9\end{array}$ \\
\hline 35 & $\begin{array}{l}\text { NS } \\
\text { NS } \\
\text { NS }\end{array}$ & $\begin{array}{l}<0.01 \\
\text { NS } \\
<0.05 \\
\text { NS }\end{array}$ & $\begin{array}{l}\text { NS } \\
\text { NS } \\
\text { NS }\end{array}$ & $\begin{array}{l}<0.02 \\
\text { NS } \\
<0.05 \\
\text { NS }\end{array}$ & $\begin{array}{l}\text { NS } \\
\text { NS } \\
\text { NS }\end{array}$ & $\begin{array}{l}\text { NS } \\
\text { NS } \\
\text { NS } \\
<0.05\end{array}$ & $\begin{array}{l}\text { NS } \\
\text { NS } \\
\text { NS }\end{array}$ & $\begin{array}{l}<0.02 \\
<0.01 \\
\text { NS } \\
\text { NS }\end{array}$ & $\begin{array}{l}\text { NS } \\
\text { NS } \\
\text { NS }\end{array}$ \\
\hline
\end{tabular}




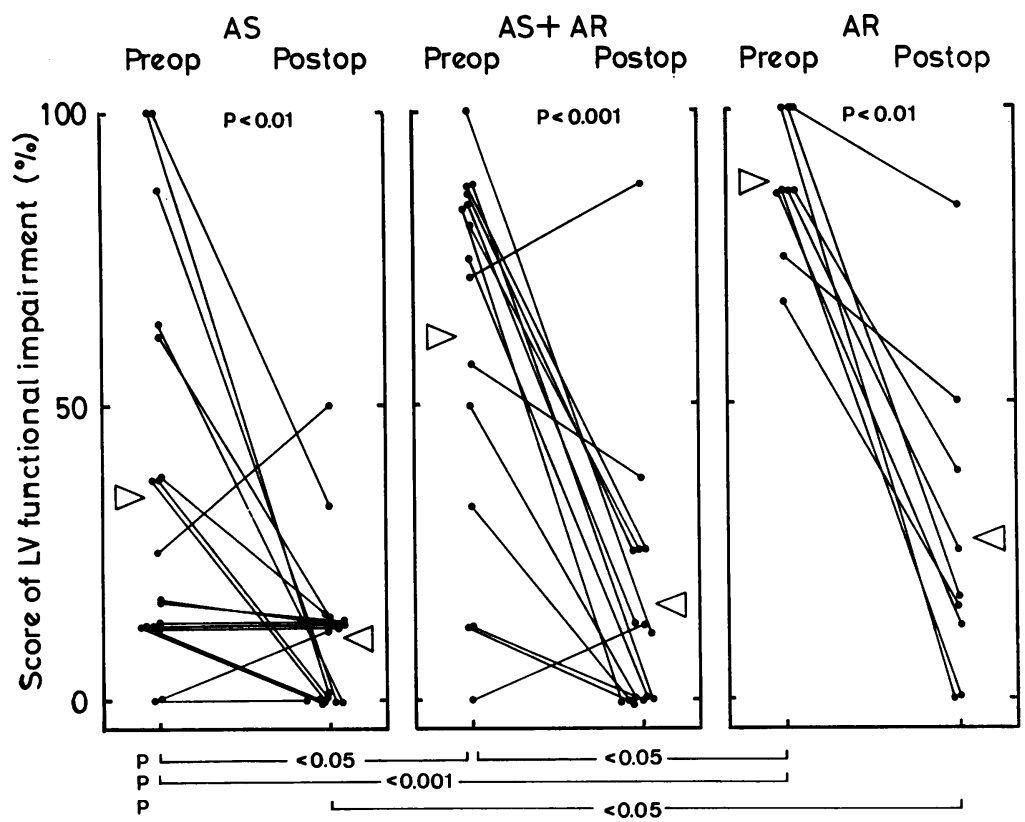

Fig. 1 Score of left ventricular ( $L V$ ) functional impairment in aortic stenosis ( $A S$ : group 1), in combined aortic stenosis and regurgitation ( $A S+A R:$ group 2), and in aortic regurgitation ( $A R:$ group 3 ). There is a significant decrease of $L V$ functional impairment after aortic valve replacement ( $P$ values inside the 3 panels; paired $t$ test). In AR the LV functional impairment is significantly greater than in $A S$ before as well as after operation ( $P$ values below the 3 panels; unpaired $t$ test). The triangles indicate the mean values.

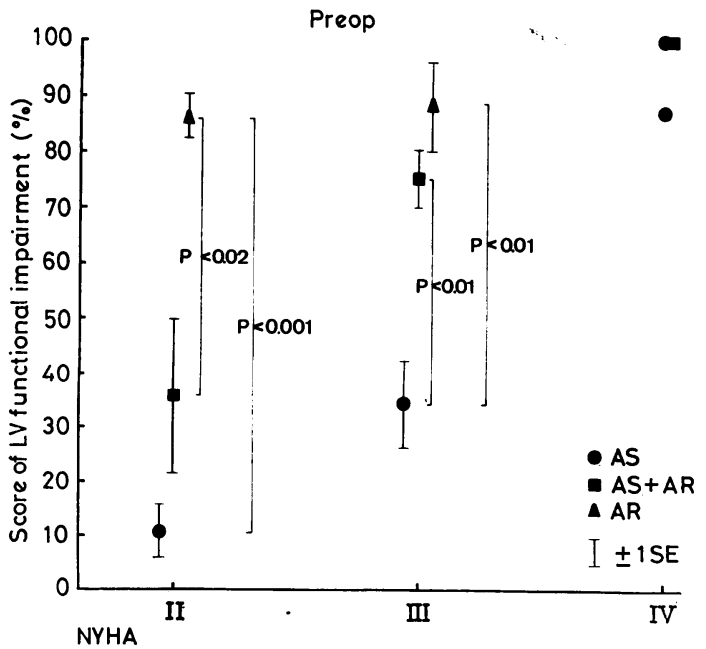

Fig. 2 Score of left ventricular ( $L V$ ) functional impairment at preoperative evaluation in the NYHA classes II, III, and IV. In the NYHA classes II and III the score of $\Phi$ left ventricular functional impairment was significantly greater in aortic regurgitation $(A R)$ than in aortic stenosis $(A S)$. The score of the patients with combined aortic valve lesion $(A S+A R)$ was intermediate. $P=$ probability (unpaired $t$ test). In the NYHA classes II and III the solid symbols represent mean values \pm 1 standard error. In the NYHA class IV the symbols represent 3 single values ( $2 A S, 1 A S+A R)$. 
Table 7 Score of potential intraoperative myocardial damage and preoperative muscle mass for three groups of patients

\begin{tabular}{|c|c|c|c|c|}
\hline & \multicolumn{2}{|c|}{$\begin{array}{l}\text { Score of left ventricular } \\
\text { functional impairment }(\%)\end{array}$} & \multirow{2}{*}{$\begin{array}{l}\text { Score of potential intraop } \\
\text { damage of myocardium } \\
\text { (points) }\end{array}$} & \multirow{2}{*}{$\begin{array}{l}\text { Left ventricular muscle } \\
\text { mass index } \\
\text { Preop }\left(g / m^{2}\right)\end{array}$} \\
\hline & Preop & Postop & & \\
\hline $\begin{array}{l}\text { Group } A(\mathrm{n}=13)^{\star} \\
\text { (maximally } 1 \mathrm{LV} \text { index pathological preop and postop) } \\
\text { Group } B(\mathrm{n}=19) \dagger \\
\quad \text { (2 or more } \mathrm{LV} \text { indices pathological preop, } \\
\text { maximally } 1 \text { index pathological postop) }\end{array}$ & 10 & 8 & $11 \cdot 6$ & 163 \\
\hline $\begin{array}{l}\text { Group } C(\mathrm{n}=11) \ddagger \\
\quad(2 \text { or more } L V \text { indices pathological preop and postop) } \\
P_{A} \text { vB B } \\
P_{A} \text { vs } C \\
P_{B} \text { v } C\end{array}$ & 78 & 44 & $\begin{array}{l}12 \cdot 6 \\
\text { NS } \\
\text { NS } \\
\text { NS }\end{array}$ & $\begin{array}{l}213 \\
\text { NS } \\
<0.05 \\
<0.1\end{array}$ \\
\hline
\end{tabular}

* Group A with minimal pre- and postoperative left ventricular (LV) functional impairment.

† Group B with depressed preoperative LV function and minimal postoperative impairment.

¥ Group $C$ with depresscd preoperative $L V$ function and postoperative residual dysfunction.

heterografts (Lurie et al., 1977) in whom there was at least some postoperative aortic regurgitation.

Although the ejection fraction is a popular and useful index for the assessment of left ventricular function and has been shown to be of predictive value in valvular heart disease (Cohn et al., 1974) it only incompletely reflects left ventricular contractile state when the loading conditions change (Sonnenblick and Strobeck, 1977). After operation afterload decreased because left ventricular peak systolic pressure and/or left ventricular dimensions were reduced. Therefore, an appraisal of left ventricuiar function should include not only ejection indices but also standard haemodynamics and isovolumic velocity indices to give the best picture of the actual state of the myocardium. Thus, using for this purpose the score of left ventricular functional impairment, we found a remarkable improvement in left ventricular contractile function in all 3 groups after valve replacement (Fig. 1). Nevertheless there remained some residual functional impairment which was significantly greater in

Table 8 Score of potential intraoperative damage (PID) and postoperative score of left ventricular functional impairment (LVFI) in relation to method of myocardial protection

\begin{tabular}{|c|c|c|c|c|}
\hline & \multirow{2}{*}{$\begin{array}{l}\text { Myocardial } \\
\text { protection }\end{array}$} & \multirow{2}{*}{$\begin{array}{l}\text { Score of PID } \\
\text { (points) }\end{array}$} & \multicolumn{2}{|c|}{ Score of $L V F I(\%)$} \\
\hline & & & Preop & Postop \\
\hline \multirow{3}{*}{$\begin{array}{l}\text { I. } \\
\text { II. } \\
\text { III. }\end{array}$} & $\begin{array}{l}30^{\circ} \text { anoxic arrest } \\
(n=13)\end{array}$ & $13 \cdot 0$ & 47 & 11 \\
\hline & $\begin{array}{l}\text { Cold coronary } \\
\text { flush }(n=24)\end{array}$ & $15 \cdot 7$ & 57 & 17 \\
\hline & $\begin{array}{l}\text { Biochemical } \\
\text { cardioplegia } \\
(n=6)\end{array}$ & $12 \cdot 8$ & 53 & 22 \\
\hline
\end{tabular}

For all three scores statistical comparisons (unpaired $t$ test) between groups I, II, and III yielded $P$ values $>0.05$. patients with aortic regurgitation than in those with aortic stenosis. The postoperative score of the patients with combined lesions was intermediate. These postoperative observations are at variance with those of Gault et al. (1970) who reported no improvement in contractile function in patients with free aortic regurgitation after operation.

\section{POSSIBLE CAUSES FOR RESIDUAL LEFT}

VENTRICULAR DYSFUNCTION

Surgery itself may represent serious trauma to the myocardium and thus may in part account for the residual left ventricular dysfunction. In order to test this hypothesis we have regrouped the 43 patients in 3 subsets according to the level of preand postoperative left ventricular contractile function (Table 7). In group A pre- and postoperative left ventricular contractile function was normal or near normal; in group B preoperative function was depressed but there was complete or nearly complete postoperative normalisation; in group C preoperative function was equally compromised as in $\mathrm{B}$, but postoperatively there was a residual left ventricular functional impairment. If surgery per se had been a significant factor in determining residual impairment of left ventricular function, the score of potential intraoperative damage should have been raised in group C. However there was no significant difference among the three subsets $A, B$, and $C$.

Moreover the type of myocardial protection used during operation appeared to have had no impact on the postoperative contractile function (Table 8).

In another attempt to identify a common preoperative factor in those patients who did not normalise left ventricular function postoperatively the extent of hypertrophy estimated from the magnitude of the left ventricular muscle mass index was determined in the subsets A, B, and C (Table 
7). It was observed that the patients with normal or near normal postoperative left ventricular function (groups $A$ and $B$ ) had a smaller preoperative muscle mass index than the patients with two or more pathological postoperative indices of left ventricular function (group C) regardless of whether or not the preoperative function was impaired (group B) or normal or near normal (group A). This finding supports the contention that in aortic valve disease massive preoperative hypertrophy, probably associated with fibrosis (Maron et al., 1975), is an adverse factor for the normalisation of postoperative left ventricular contractile function.

\section{CONCLUSIONS ON INDICATION FOR AORTIC VALVE REPLACEMENT}

In the last few years the operative mortality of aortic valve replacement has decreased to 2 to 4 per cent and has even been abolished as reported recently (Karp and Lell, 1976). Therefore survival alone cannot any longer be considered to be the criterion for success (Galyean et al., 1974). In our opinion a legitimate requirement in 1978 has to be a complete or nearly complete normalisation of left ventricular contractile function after surgery. However, this goal can only be achieved if preoperative impairment of left ventricular contractile function is not too far advanced. With this objective in mind it appears to be safe in aortic stenosis to wait until symptoms of class II to III (NYHA) occur. On the other hand, in aortic regurgitation a similar overall functional limitation is associated with significantly greater impairment of left ventricular function which is only partially reversible after operation. Thus, we recommend that aortic valve replacement should be carried out in patients with haemodynamically important aortic regurgitation as soon as mild symptoms occur.

\section{References}

Barnhorst, D. A., Oxman, H. A., Connolly, D. C., Pluth, J. R., Danielson, G. K., Wallace, R. B., and McGoon, D. C. (1975). Isolated replacement of the aortic valve with the Starr-Edwards prosthesis. Fournal of Thoracic and Cardiovascular Surgery, 70, 113-118.

Björk, V. O., Henze, A., and Holmgren, A. (1973a). Central haemodynamics at rest and during exercise before and after aortic valve replacement with the Björk-Shiley tilting disc valve in patients with isolated aortic stenosis. Scandinavian fournal of Thoracic and Cardiovascular Surgery, 7, 111-130.

Björk, V. O., Henze, A., and Holmgren, A. (1973b). Central haemodynamics at rest and during exercise before and after operation with the Björk-Shiley tilting disc valve in patients with aortic incompetence. Scandinavian Fournal of Thoracic and Cardiovascular Surgery, 7, 214-225.

Björk, V. O., Henze, A., and Holmgren, A. (1974). Five years' experience with the Björk-Shiley tilting-disc valve in isolated aortic valvular disease. Fournal of Thoracic and Cardiovascular Surgery, 68, 393-403.
Brunner, H. H., Steiger, U., Goebel, N. H. J., and Krayenbuehl, H. P. (1977). Left ventricular contractile function in aortic stenosis evaluated by isovolumic and ejection phase indexes. American Heart fournal, 93, 147-159.

Cohn, P. F., Gorlin, R., Cohn, L. H., and Collins, J. J., Jr. (1974). Left ventricular ejection fraction as a prognostic guide in surgical treatment of coronary and valvular heart disease. American fournal of Cardiology, 34, 136-141.

Doces, J., Stewart, D., and Kennedy, J. W. (1974). Quantitative assessment of left ventricular function following successful aortic valve replacement (abstract). Circulation, 49 and 50, Suppl. 1II, 7.

Galyean, I. R., Suzuki, A., and Blake, T. M. (1974). Surgery for aortic valve disease. Editorial. American Heart fournal, 88, 683-685.

Gault, J. H., Covell, J. W., Braunwald, E., and Ross, J., Jr. (1970). Left ventricular performance following correction of free aortic regurgitation. Circulation, 42, 773-780.

Hirshfeld, J. W., Jr., Epstein, S. E., Roberts, A. J., Glancy, D. L., and Morrow, A. G. (1974). Indices predicting longterm survival after valve replacement in patients with aortic regurgitation and patients with aortic stenosis. Circulation, 50, 1190-1199.

Hultgren, H. N., Hubis, H., and Shumway, N. (1969). Cardiac function following prosthetic aortic valve replacement. American Heart fournal, 77, 585-597.

Isom, O. W., Dembrow, J. M., Glassman, E., Pasternack, B. S., Sackler, J. P., and Spencer, F. C. (1974). Factors influencing longterm survival after isolated aortic valve replacement. Circulation, 49 and 50, Suppl. II, 154-161.

Karp, R. B., and Lell, W. (1976). Evaluating techniques of myocardial preservation for aortic valve replacement: operative risk. Fournal of Thoracic and Cardiovascular Surgery, 72, 206-208.

Kennedy, J. W., Twiss, R. D., Blackmon, J. R., and Merendino, K. A. (1968). Hemodynamic studies one year after homograft aortic valve replacement. Circulation, 37 and 38, Suppl. II, 110-118.

Kloster, F. E., Farrehi, C., Mourdjinis, A., Hodam, R. P., Starr, A., and Griswold, H. E. (1970). Hemodynamic studies in patients with cloth-covered composite-seat StarrEdwards valve prostheses. Fournal of Thoracic and Cardiovascular Surgery, 60, 879-888.

Krayenbuehl, H. P., Rutishauser, W., Wirz, P., Amende, I. and Mehmel, H. (1973). High-fidelity left ventricular pressure measurements for the assessment of cordiac contractility in man. American fournal of Cardiology, 31, 415427.

Kreulen, T. H., Bove, A. A., McDonough, M. T., Sands, M. J., and Spann, J. F. (1975). The evaluation of left ventricular function in man: a comparison of methods. Circulation, 51, 677-688.

Lee, S. J. K., Haraphongse, M., Callaghan, J. C., Rossall, R. E., and Fraser. R. S. (1970). Hemodynamic changes following correction of severe aortic stenosis using the Cutter-Smelcff prosthesis. Circulation, 42, 719-728.

Lurie, A. J., Miller, R. R., Maxwell, K. S., Grehl, T. M., Vismara, L. A., Hurley, E. J., and Mason, D. T. (1977). Hemodynamic assessment of the glutaraldehyde-preserved porcine heterograft in the aortic and mitral positions. Circulation, 55 and 56, Suppl. II, 104-110.

Maron, B. J., Ferrans, V. J., and Roberts, W. C. (1975). Myocardial ultrastructure in patients with chronic aortic valve disease. American fournal of Cardiology, 35, 725-739.

Mirsky, I., Ellison, R. C., and Hugenholtz, P. G. (1971). Assessment of myocardial contractility in children and young adults from ventricular pressure recordings. American fournal of Cardiology, 27, 359-367.

Peterson, K. L., Skloven, D., Ludbrook, P., Uther, J. B., and Ross, J. Jr. (1974). Comparison of isovolumic and ejection 
phase indices of myocardial performance in man. Circulation, 49, 1088-1101.

Rackley, C. E., Dodge, H. T., Coble, Y. D., and Hay, R. E. (1964). A method for determining left ventricular mass in man. Circulation, 29, 666-671.

Rothlin, M. E., Krayenbühl, H. P., Messmer, B. J., and Senning, A. (1977). Langzeitverlauf nach Aorten- und Mitralklappenersatz. Herz, 2, 268-274.

Schmutzler, H., Grosse, G., Rutsch, W., Paeprer, H., Michel, U., and Krais, T. (1976). Ventricular function in valvular heart disease before and after prosthetic valve surgery. In
Ventricular Function at Rest and During Exercise, pp. 125127. Ed. by H. Roskamm and Ch. Hahn. Springer, Berlin. Sonnenblick, E. H., and Strobeck, J. E. (1977). Current concepts in cardiology. Derived indexes of ventricular and myocardial function. New England fournal of Medicine, 296, 978-982.

Requests for reprints to Dr H. P. Krayenbuehl, Medical Policlinic, Cardiology, Raemistrasse 100, 8091 Zurich, Switzerland. 